\title{
Consortial Effect of Endophytic and Plant Growth Promoting Rhizobacteria for the Management of Early Blight of Tomato Incited by Alternaria Solani
}

Subramaniam Sundaramoorthy* and Ponnusamy Balabaskar

Department of Plant Pathology, Faculty of Agriculture, Annamalai University, Chidambaram 608002, Tamil Nadu, India

\begin{abstract}
Tomato, early blight caused by Alternaria solani has been known to cause severe yield losses. Hence, attempts were made to develop an effective ecofriendly strategy to manage the disease using endophytic and plant growth promoting rhizobacteria. Accordingly, the strains of Bacillus subtilis (EPCO16 and EPC5) and Pseudomonas fluorescens (Pf, Py15 and Fp7) were tested individually and in combination for their effectiveness against early blight of tomato incited by $A$. solani under in vitro and pot culture conditions. The results revealed that the strains of Bacillus subtilis and Pseudomonas fluorescens were compatible. Under in vitro conditions the combined application of EPCO16+Pf1 was found to effectively inhibit the mycelial growth of the pathogen and promote the growth of tomato seedlings when compared to application of individual strains of the antagonists. Further, a significant reduction in early blight incidence of tomato under greenhouse conditions was observed due to the combined application of EPCO16+Pf1. These findings suggest that synergistic consortia of biocontrol agents may be successfully employed as an eco-friendly strategy for the management of early blight of tomato.
\end{abstract}

Keywords: Alternaria solani; Early blight; Tomato; Pseudomonas fluorescens; Bacillus subtilis

\section{Introduction}

The area under Tomato (Lycopersicon esculentum Mill.) cultivation is on the increase due to its fleshy fruits with high nutritive value. It occupies number one position in its nutrient contribution to human diet. In Tamil Nadu, tomato is grown in an area of $22,433 \mathrm{ha}$, with a production of 2,82,912 tonnes and a productivity of $12,611 \mathrm{~kg} / \mathrm{ha}$ [1]. The crop is known to be affected by a number of diseases among which, early blight caused by Alternaria solani (Ellis and Martin) causes yield losses up to $80 \%[2,3]$. The disease manifests as leaf spots with dark brown to black concentric rings which later coalesce and results in blighting of leaves; defoliation and shedding of immature fruits. Also, dark spots and sunken lesions appear near the base of stem resulting in stunting and girdling of stem. Presently, the management of tomato early blight disease has been done with the application of chemical fungicides. However, it may not be sustainable in the longer run as chemical fungicides are known to cause residual toxicity, toxicity to non-target organisms and other environmental hazards. Therefore, recent efforts have been focused on developing eco-friendly, safe, long lasting and effective management strategy for the management of plant diseases $[4,5]$.

Use of biocontrol agents has been shown to be eco-friendly and effective against many plant pathogens and pest. Accumulating evidences suggest that the organisms under most scrutiny for potential use in biological control of pest and diseases are bacteria belonging to the genera Pseudomonas and Bacillus [6]. Further, Plant Growth Promoting Endophytic bacteria (PGPE), especially Bacillus subtilis (EPCO16 and EPC5) and Plant Growth Promoting Rhizobacteria (PGPR), especially Pseudomonas fluorescens (Pf1, Py15 and Fp7) strains have been developed commercially as a talc based formulation and tested against several crop diseases [7-10]. Recently, Sundaramoorthy et al. [5] reported that combination of $P$. fluorescens strain (Pf1) and $B$. subtilis strain (EPCO16) effectively inhibited the growth of the F. solani in chilli plants. Several approaches have been tried for the sustainable management of early blight in tomato. However, no attempts have been made for the management of early blight disease with mixtures of both PGPR and PGPE strains. Therefore, the present study was designed to evaluate protective effect of endophytic bacterial strains, B. subtilis (EPCO16 and EPC5) and rhizobacterial strains P. fluorescens (Pf1, Py15 and Fp7) against tomato early blight disease caused by $A$. solani.

\section{Materials and Methods}

\section{Isolation of pathogen and maintenance of biocontrol agents}

A. solani taken from infected tissue of diseased fruits of tomato were inoculated on water agar medium $(2 \% ; 2 \mathrm{~g}$ agar/100ml of sterile distillate water) and incubated at $25^{\circ} \mathrm{C}$ for 3 days. After incubation, single spore colony was transferred to the Petri dishes containing Potato Dextrose Agar (PDA) to obtain pure culture of the pathogen. The commercially released endophytic bacterial strains $B$. Subtilis (EPCO16 and EPC 5) isolated from coconut and cotton respectively and the rhizobacterial strains of $P$. fluorescens (Pf1, Py15 and Fp7) were obtained from the culture collection of Department of Plant Pathology, Tamil Nadu Agricultural University (TNAU), Coimbatore, India. The strains of B. Subtilis were maintained on Nutrient Agar (NA) slants and $P$. fluorescens strains were maintained on King's B (KB) slants at $4^{\circ} \mathrm{C}$.

\section{Compatibility among bacterial strains}

The isolates of Pseudomonas and Bacillus were tested for their compatibility among each other following the method of Fukui et al. [11]. The compatibility was determined for P. fluorescens and $B$. subtilis strains using NA medium. The bacterial strains were streaked

*Corresponding author: Subramaniam Sundaramoorthy, Department of Plant Pathology, Faculty of Agriculture, Annamalai University, Chidambaram 608002 , Tamil Nadu, India, E-mail: sundardivi@gmail.com

Received October 17, 2012; Accepted November 19, 2012; Published November 24, 2012

Citation: Sundaramoorthy S, Balabaskar P (2012) Consortial Effect of Endophytic and Plant Growth Promoting Rhizobacteria for the Management of Early Blight of Tomato Incited by Alternaria Solani. J Plant Pathol Microb 3:145. doi:10.4172/21577471.1000145

Copyright: () 2012 Sundaramoorthy S, et al. This is an open-access article distributed under the terms of the Creative Commons Attribution License, which permits unrestricted use, distribution, and reproduction in any medium, provided the original author and source are credited. 
horizontally and vertically to each other. The plates were incubated at room temperature $\left(28 \pm 2^{\circ} \mathrm{C}\right)$ for $72 \mathrm{~h}$ and observed for the inhibition zone. Absence of inhibition zone indicates the compatibility with respective bacterial strains and the presence of inhibition zone indicated the incompatibility.

\section{In vitro evaluation of individual and combined biocontrol agents against $A$. solani}

The mycelial disc $(9 \mathrm{~mm})$ of the tomato early blight pathogen Alternaria solani was placed in the centre of the petri plate. Sterile filter paper discs $(6 \mathrm{~mm})$ were placed one $\mathrm{cm}$ away from the edge at four sides centring the fungal disc. Twenty five micro litres of bacterial broth culture $\left(9 \times 10^{8} \mathrm{cfu} \mathrm{ml}^{-1}\right)$ of each strain were dropped over the filter paper discs. Observation was taken after seven days for the presence of inhibition zone. Control was maintained with sterile distilled water instead of bacterial inoculum. The radial growth of the pathogen and per cent reduction over control was calculated by using the formula,

$$
\text { Percent reduction over control }=\frac{\mathrm{CT}}{\mathrm{T}} \times 100
$$

Where C-Mycelial growth of the pathogen in control $(\mathrm{mm})$ and $\mathrm{T}-$ Mycelial growth of the pathogen in dual plate $(\mathrm{mm})$.

\section{In vitro efficacy of biocontrol agents on growth parameters of tomato seed bacterization}

Seeds (One gram) of tomato cv. PKM1 surface-sterilized with $2 \%$ sodium hypochlorite for 20 seconds; rinsed in sterile distilled water and dried overnight were treated with Ten $\mathrm{ml}$ of biocontrol inoculums containing not less than $3 \times 10^{8} \mathrm{cfu} \mathrm{ml}^{-1}$. One hundred mg of Carboxy Methyl Cellulose (CMC) was added as an adhesive material. The treated seeds were kept for two hours and air-dried overnight in a sterile Petri dish and used for sowing.

\section{Plant growth-promotion}

The plant growth-promoting activity of the biocontrol agents was assessed based on the seedling vigour index by the standard roll towel method [12]. Seed bacterization was done as described above. Twentyfive treated seeds were placed on a pre-soaked germination paper. The seeds were held in position with another germination paper strip and gently pressed. The polythene sheet along with the seeds was then rolled up and incubated in a growth chamber for 10 days. Three replications for each treatment and a suitable control were also maintained. After incubation, the root length and shoot length of individual seedlings were measured and the per cent germination was calculated. The seedling vigour index was calculated using the formula, Vigour Index= (mean root length + mean shoot length) $\times \%$ germination [13].

\section{Preparation of individual and mixture of PGPE and PGPR bioformulations}

A loopful of $P$. fluorescens and B. subtilis were inoculated into the sterilized KB and Nutrient broth, respectively and incubated in a rotary shaker at $150 \mathrm{rpm}$ for $48 \mathrm{~h}$ at room temperature $\left(28 \pm 2^{\circ} \mathrm{C}\right)$. After $48 \mathrm{~h}$ of incubation, the broth containing $9 \times 10^{8} \mathrm{cfu} / \mathrm{ml}$ was used for the preparation of talc-based formulation. To $400 \mathrm{ml}$ of bacterial suspension, $1 \mathrm{~kg}$ of talc powder (sterilized at $105^{\circ} \mathrm{C}$ for $12 \mathrm{~h}$ ), calcium carbonate $15 \mathrm{~g}$ (to adjust the $\mathrm{pH}$ to neutral) and Carboxy Methyl Cellulose (CMC) 10g (adhesive) were mixed under sterile conditions, following the method described by [14]. After shade drying overnight, it was packed in polypropylene bag and sealed. At the time of application the population of bacteria in talc formulation was not less than 2.5$3 \times 10^{8} \mathrm{cfu} / \mathrm{g}$. For bacterial strain mixture, the bacterial strains were grown separately and the strains that are going to make up the mixture were added equally (v/v) and finally mixed with talc powder, $\mathrm{CaCO}_{3}$ and $\mathrm{CMC}$ [14].

Efficacy of bio-formulation mixture on the incidence of $A$. solani disease under greenhouse conditions

A pot culture experiment was conducted with individual and combination of rhizosphere and endophytic bacteria treatments. Seeds of tomato cv. PKM1 were sown in earthen pots (Size- $0.35 \mathrm{~m}$ diameter, $0.50 \mathrm{~m}$ height, volume of soil: $0.04 \mathrm{~m}^{3}$ ) filled with sterilized potting soil @ five seeds per pot. The talc-based product was dissolved in water $(20$ $\mathrm{g} / \mathrm{l}$ ) and allowed to settle for $1 \mathrm{~h}$, filtered through muslin cloth and the filtrate was used for spray. The fungicide mancozeb $0.2 \%$ spray was used as a positive control. The talc-based bioformulation mixtures were sprayed at 45 days after sowing and one day after spray, the plants were inoculated with the spore suspension $\left(5 \times 10^{6}\right.$ spores $\left./ \mathrm{ml}\right)$ of $A$. solani. The plants inoculated with the pathogen alone served as inoculated control. Ten days after inoculation, observations on development of early blight symptoms were made. Three replications were maintained for each treatment; each replication consisted of five pots and in each pot four plants were maintained in completely a randomized design under glasshouse conditions. The trial was repeated once and the data presented were the pooling of two glasshouse trials. The intensity of the disease was recorded in each treatment following the 0-9 scale score chart (0- Healthy; $1-1$ to $5 \%$; $3-6$ to $10 \%$; $5-11$ to $25 \%$; $7-26$ to $50 \%$ and $9-51 \%$ leaf area infected) proposed by Ramakrishnan et al. [15]. The Percent Disease Index (PDI) was estimated using the formula suggested by Mckinney [16].

\section{Statistical analysis}

The data were analyzed by analysis of variance (ANOVA), and treatment means were compared by Duncan's Multiple Range Test (DMRT) at 5\% level. The data on disease severity were arcsine transformed before undergoing statistical analysis [17].

\section{Results}

\section{Compatibility among bacterial strains}

PGPR strains of $P$. fluorescens (Pf1, Py15 and Fp7) and PGPE strains of B. subtilis (EPCO16 and EPC 5) were tested for their compatibility in vitro. None of the antagonistic bacteria inhibited each other, suggesting that these bacterial biocontrol agents were compatible with each other.

\section{Effect of biocontrol agents on radial mycelial growth of $A$ solani}

PGPR and PGPE strains were tested individually and in combination to assess the radial growth of $A$. solani. All the treatments were effective in reducing the mycelia growth of the pathogen. However, the combined application of EPCO16+Pf1 resulted in the least mycelial growth with $58.5 \mathrm{~mm}$. The control plates recorded the highest mycelial growth of $85.5 \mathrm{~mm}$ (Table 1).

Values are mean of three replications; Data in parentheses are arcsine transformed values. In column, means followed by a common letter are not significantly different at $5 \%$ level by DMRT. 


\begin{tabular}{|l|l|l|l|}
\hline Treatment No. & Biocontrol strains & Linear growth $(\mathrm{cm})$ & Reduction (\%) \\
\hline T1 & Pf1 & $74.5(59.7)$ & 12.5 \\
\hline T2 & Py15 & $78.5(62.8)$ & 7.5 \\
\hline T3 & Fp7 & $76.5(61.8)$ & 7.7 \\
\hline T4 & EPC5 & $78.7(62.8)$ & 8.3 \\
\hline T5 & EPCO16 & $68.5(55.9)$ & 19.5 \\
\hline T6 & EPCO16+Pf1 & $58.5(49.9)$ & 31.5 \\
\hline T7 & Mancozeb (0.2\%) & $54.5(46.6)$ & 36.5 \\
\hline T8 & Control & $85.5(68.4)$ & 0.0 \\
\hline
\end{tabular}

Table 1: Effect of biocontrol agents on the mycelial growth of $A$. solani.

\begin{tabular}{|l|l|l|l|l|l|}
\hline $\begin{array}{l}\text { Treatment } \\
\text { No. }\end{array}$ & $\begin{array}{l}\text { Biocontrol } \\
\text { strains }\end{array}$ & $\begin{array}{l}\text { Germination } \\
(\%)\end{array}$ & $\begin{array}{l}\text { Shoot length } \\
(\mathrm{cm})\end{array}$ & $\begin{array}{l}\text { Root length } \\
(\mathrm{cm})\end{array}$ & Vigour index \\
\hline T1 & Pf1 & $93.0(76.0)$ & 15.6 & 18.2 & 3143.40 \\
\hline T2 & Py15 & $88.5(71.1)$ & 15.5 & 17.8 & 2947.05 \\
\hline T3 & Fp7 & $89.5(72.5)$ & 15.5 & 17.9 & 2989.30 \\
\hline T4 & EPC5 & $88.5(71.1)$ & 14.9 & 16.9 & 2814.30 \\
\hline T5 & EPCO16 & $93.5(76.5)$ & 16.1 & 18.4 & 3225.75 \\
\hline T6 & EPCO16+Pf1 & $96.5(80.3)$ & 18.6 & 21.2 & 3840.70 \\
\hline T7 & $\begin{array}{l}\text { Mancozeb } \\
(0.2 \%)\end{array}$ & $90.5(70.2)$ & 16.2 & 19.5 & 3230.85 \\
\hline T8 & Control & $80.0(62.8)$ & 14.3 & 16.4 & 2456.0 \\
\hline
\end{tabular}

Table 2: Efficacy of seed treatment with PGPR and PGPE strains on plant growth promotion under in vitro conditions.

\begin{tabular}{|l|l|l|l|}
\hline Treatment No. & Bio control strains & Disease severity (\%) & Reduction (\%) \\
\hline T1 & Pf1 & 32.1 & 45.3 \\
\hline T2 & Py15 & 32.8 & 44.1 \\
\hline T3 & Fp7 & 34.8 & 40.2 \\
\hline T4 & EPC5 & 39.4 & 36.5 \\
\hline T5 & EPCO16 & 30.4 & 48.2 \\
\hline T6 & EPCO16+Pf1 & 22.6 & 61.5 \\
\hline T7 & Mancozeb (0.2\%) & 18.1 & 69.2 \\
\hline T8 & Control & 54.1 & 0.0 \\
\hline
\end{tabular}

Table 3: Efficacy of PGPR and PGPE strains on early blight incidence of tomato under greenhouse conditions.

\section{Effectiveness of PGPR and PGPE strains in plant growth promotion}

The treatment with biocontrol combination of Pf1+EPCO16 produced significantly higher vigour index (3840.70) of tomato seedlings than did the individual biocontrol strains Pf1, Py15, Fp7, EPC5 and EPCO16, whose vigour index recorded were 3143.40, $2947.05,2989.30,2814.30$ and 3225.75 respectively. The untreated control seedlings had the lowest vigour index (2456.0) (Table 2).

\section{Effectiveness of PGPR and PGPE strains on early blight incidence under greenhouse conditions}

All of the treatments with biocontrol strains significantly reduced the PDI (by 35-61\%) compared to untreated control, and increased the seed germination (by 88-96\%) (Table 3). Conspicuously, the treatment with a combination of Pf1+EPCO16 resulted in a significantly lower early blight disease severity than any of the strains treated individually.

Values are mean of three replications. Data in parentheses are arcsine transformed values. In column, means followed by a common letter are not significantly different at $5 \%$ level by DMRT.

\section{Discussion}

Accumulating evidence from literature has shown that compatible multiple strains appear to be an important pre-requisite for the desired effectiveness of strains and more consistent disease suppression $[4,5,18]$. The results of the present study provide evidence that the $P$. fluorescens strains (Pf1, Py15 and Fp7) and B. Subtilis strains (EPCO 16 and EPC5) were compatible and effectively inhibited the growth of $A$. solani. Earlier it has been reported that the bio control agents such as Trichoderma viride and $P$. fluorescens significantly reduced the mycelial growth, spore germination, spore production and germ tube formation of A. solani and A. alternata [19]. Several strains of Pseudomonas and Bacillus spp. have been reported to produce wide array of antibiotics viz., 2,4, diacetylphloroglucinol, oligomycin, phenazine, pyoluteorin, pyrolnitrin, pyocyanin, iturin, bacillomycin, zwittermycin $\mathrm{A}$ and surfactin which are responsible for their antifungal action [20]. Results from the present study clearly indicated maximum reduction in mycelia growth due to the combination of biocontrol strains than individual strains suggesting the synergism among biocontrol agents in reducing the mycelia growth of the pathogen.

Similarly, the treatment with combination of Pf1+EPCO16 increased the plant growth of tomato more than did individual biocontrol strains. Similar results on increased root and shoot length due to combined application of Pf1+Py15+Bs16+Zimmu in tomato [4] and chilli [5] were also reported. In the pot culture studies also the treatment with combination of Pf1+EPCO16 resulted in a significantly lower early blight disease severity than any of the strains treated individually. Earlier mixtures of PGPR strains were reported to suppress sheath blight in rice more than the individual PGPR strains [14]. Although the chemical treatment with Mancozeb (0.2\%) recorded the least disease severity it is noteworthy to observe that the treatment with combination with Pf1+EPCO16 also produced almost comparable results in reducing the disease severity. Thus the eco-friendly nature of antagonistic bacterial formulations is advantageous over the use of chemical fungicides.

\section{Conclusion}

The results of the present study demonstrated that combined application of Pf1+EPCO16 (endophytic and rhizosphere bacterial strains) is a promising approach for the eco friendly management of early blight disease caused by $A$. solani and enhancing the growth of the tomato plants.

\section{References}

1. Anonymous (2007) Season and Crop report of Tamil Nadu. Department of Economics and Statistics, Chennai.

2. Singh RS (1985) Diseases of Vegetable Crops. Oxford and IBH Publishing Co., New Delhi, Bombay, Calcutta, 346.

3. Chandravanshi SS, Singh BP, Thakur MP (1994) Persistence of different fungicides used against Alternaria alternata in tomato. Indian Phytopathology 47: 241-244.

4. Latha P, Anand T, Ragupathi N, Prakasam V, Samiyappan R (2009) Antimicrobia activity of plant extracts and induction of systemic resistance in tomato plants by mixtures of PGPR strains and zimmu leaf extract against Alternaria solani. Biological Control 50: 85-93.

5. Sundaramoorthy S, Raguchander T, Ragupathi N, Samiyappan R (2012) Combinatorial effect of endophytic and plant growth promoting rhizobacteria against wilt disease of Capsicum annum L. caused by Fusarium solani. Biological Control 60: 59-67.

6. Ramamoorthy V, Viswanathan R, Raguchander T, Prakasam V, Samiyappan R (2001) Induction of systemic resistance by plant growth promoting rhizobacteria in crop plants against pests and diseases. Crop Protection 20: 1-11.

7. Rajendran L, Saravanakumar D, Raguchander T, Samiyappan R (2006) Endophytic bacterial induction of defence enzymes against bacterial blight of cotton. Phytopathol Mediterr 45: 203-214. 
Citation: Sundaramoorthy S, Balabaskar P (2012) Consortial Effect of Endophytic and Plant Growth Promoting Rhizobacteria for the Management of Early Blight of Tomato Incited by Alternaria Solani. J Plant Pathol Microb 3:145. doi:10.4172/2157-7471.1000145

8. Rajendran L, Karthikeyan G, Raguchander T, Samiyappan R (2007) In vitro evaluation of bacterial endophytes influence on Ganoderma lucidum (Leys) Karst. mycelial growth. J Plant Protect Res 47: 425-436.

9. Kavino M, Harish S, Kumar N, Saravanakumar D, Domodaran T, et al. (2007) Rhizosphere and endophytic bacteria for induction of systemic resistance of banana plantlets against bunchy top virus. Soil Biol Biochem 39: 1087-1098.

10. Harish S, Kavino M, Kumar N, Saravanakumar D, Soorianathasundaram $\mathrm{K}$, et al. (2008) Biohardening with plant growth promoting rhizosphere and endophytic bacteria induces systemic resistance against banana bunchy top virus. Appl Soil Ecol 39: 187-200.

11. Fukui R, Schroth MN, Hendson M, Hancock JG (1994) Interaction between strains of pseudomonads in sugar beet spermospheres and their relationship to pericarp colonization by Pythium ultimum in soil. Phytopathology 84: 13221330.

12. ISTA (1993) Proceedings of the International Seed Test Association, International rules for seed testing. Seed Science and Technology 21: 1-152.

13. Abdul-Baki AA, Anderson JD (1973) Vigor determination in soybean seed by multiple criteria. Crop Sci 13: 630-633.

14. Nandakumar R, Babu S, Viswanathan R, Sheela J, Raguchander T, et al.
(2001) A new bio-formulation containing plant growth promoting rhizobacterial mixture for the management of sheath blight and enhanced grain yield in rice. BioControl 46: 493-510.

15. Ramakrishnan L, Kamalnathan S, Krishnamurthy CS (1970) Studies on Alternaria leaf spot of tomato. Madras Agricultural Journal 57.

16. Mckinney HH (1923) A new system of grading plant diseases. J Agric Res 26 195-218.

17. Gomez KA, Gomez AA (1984) Statistical Procedures for Agricultural Research. John Wiley and Sons, New York.

18. Ganeshmoorthi P, Anand T, Prakasam V, Bharani M, Ragupathi N, et al (2008) Plant Growth Promoting Rhizobacteria (PGPR) bioconsortia mediates induction of defense related proteins against infection of root rot pathogen in mulberry plants. J Plant Interact 3: 233-244.

19. Veerasamy K (1997) Studies on the Management of Leaf Blight Disease of Brinjal Caused by Alternaria solani and Alternaria alternata (Fr.) Keissler, PhD Thesis. Tamil Nadu Agricultural University, Coimbatore, India, 144.

20. Yu GY, Sinclair JB, Hartman GL, Bertagnolli BL (2002) Production of iturin A by Bacillus amyloliquefaciens suppressing Rhizoctonia solani. Soil Biol Biochem 34: 955-963. 